


\section{Trade of the Tricks}

I NSIDE THE M A GICIA N"S CR A F T

G R A H A M M . J O N E S

\section{甲}

U N I VERSITY OF CALIFOR N A PRES

Berkeley Los Angeles London 
University of California Press, one of the most distinguished university presses in the United States, enriches lives around the world by advancing scholarship in the humanities, social sciences, and natural sciences. Its activities are supported by the UC Press Foundation and by philanthropic contributions from individuals and institutions. For more information, visit www.ucpress.edu.

University of California Press

Berkeley and Los Angeles, California

University of California Press, Ltd.

London, England

(C) 2011 by The Regents of the University of California

Library of Congress Cataloging-in-Publication Data

Jones, Graham M.

Trade of the tricks : inside the magician's craft / Graham M. Jones. p. $\mathrm{cm}$.

Includes bibliographical references and index. ISBN 978-0-520-27046-6 (cloth : alk. paper)

ISBN 978-0-520-27047-3 (pbk. : alk. paper)

1. Magic tricks. I. Title.

GV1547.J57 2011

$793.8-$ dc22

2011011165

Manufactured in the United States of America

$\begin{array}{llllllllll}20 & 19 & 18 & 17 & 16 & 15 & 14 & 13 & 12 & 11\end{array}$

$\begin{array}{llllllllll}10 & 9 & 8 & 7 & 6 & 5 & 4 & 3 & 2 & 1\end{array}$

In keeping with a commitment to support environmentally responsible and sustainable printing practices, UC Press has printed this book on Rolland Enviro100, a 100\% post-consumer fiber paper that is FSC certified, deinked, processed chlorine-free, and manufactured with renewable biogas energy. It is acid-free and EcoLogo certified. 
To Mom and Dad

Presto! 
